\title{
Protective Effects of Honey, Apis mellifera Meda Skorikov, on Ischemia-Reperfusion Induced Muscle Injury
}

\author{
Efectos Protectores de la Miel, Apis mellifera Meda Skorikov, \\ sobre la Lesión Muscular Inducida por Isquemia-Reperfusión
}

\begin{abstract}
Mohammad Reza Gholami ${ }^{1}$; Abolfazl Abbaszadeh ${ }^{2}$; Khatereh Anbari ${ }^{3}$; Mojtaba Khaksarian ${ }^{2}$; Fatemeh Shabooni ${ }^{4}$ Zahra Khanipour Khayat ${ }^{2}$; Reza Mohammadrezaei Khorramabadi ${ }^{4}$ \& Anneh Mohammad Gharravi ${ }^{5}$
\end{abstract}

GHOLAMI, M. R.; ABBASZADEH, A.; ANBARI, K.; KHAKSARIAN, M.; SHABOONI, F.; KHAYAT, Z. K.; KHORRAMABADI, R. M. \& GHARRAVI, A. M. Protective effects of honey, Apis mellifera meda skorikov, on ischemia-reperfusion induced muscle injury. Int. J. Morphol., 38(3):804-810, 2020.

SUMMARY: Honey is a natural antioxidant that its protective effects have been proven against ischemia-reperfusion (IR) injury. The aim of this study was to evaluate the ameliorative effect of Persian Honey, Apis mellifera meda skorikov, on gastrocnemius muscle IR injury. Eighty adult male Sprague-Dawley rats weighing $250-300 \mathrm{~g}$ were used. They were divided into ten groups (N=8 per group). The ischemia was conducted with a silk suture 6-0 using the slipknot technique. All groups were rendered in ischemic for $3 \mathrm{~h}$, and reperfused for various times of 3 days (3-day reperfusion), 7 days (7-day reperfusion), 14 days (14-day reperfusion), and 28 days (28-day reperfusion). Half of the groups had experimental honey (5\%) treatment immediately after ischemia. After reperfusion, the rats, based on the grouping, were killed with high doses of anesthetic, and the gastrocnemius muscles were removed and fixed. After the tissue processing, the evaluation of edema and mast cells infiltration was performed with hematoxylin-eosin and toluidine blue staining, respectively. TNF- $\alpha$ was detected with immunohistochemistry method. The amount of TNF- $\alpha$ as an index of acute inflammatory except the 3 rd day significantly decreased on the other day of reperfusion $\left({ }^{7 \text { th }}, 14^{7 \text { th }}\right.$ and $28^{\text {th }}$ days). The mast cells infiltration was significantly decreased on $7^{\text {th }}$ and $14^{7 \text { th }}$ days. The tissue edema was decreased significantly in honey administrated group in the comparison with placebo groups. Honey administration can reduce damage caused by ischemia-reperfusion in the rat gastrocnemius muscle.

KEY WORDS: Honey; Ischemia-reperfusion Injury; Gastrocnemius Muscle; Rat.

\section{INTRODUCTION}

Ischemia is characterized by decrease in blood flow that is usually caused by disruption in oxygen and nutrients delivery to the tissues (Aksu et al., 2015). After systemic events that occur during ischemia such as impairment of energy production, toxic metabolites production and cell damage, a series of circumstances is started by reperfusion including free radicals generation, acute inflammatory responses, lipid peroxidation, protein and DNA damage and finally development of cell necrosis (Dong et al., 2014; Jalili et al., 2015; Joshi et al., 2016; Salahshoor et al., 2015, 2016). It has been proved that free radicals especially reactive oxygen species (ROS) reactive nitrogen species (RNS) and inflammatory cells such as neutrophils are involved in the multifactorial pathophysiology of ischemia-reperfusion injury (IRI). Different organs in the body could be damaged by ischemia-reperfusion (IR) such as brain, heart, kidneys, skeletal muscles, etc (Gillani et al., 2012; Gharravi et al., 2016). Many conditions are able to create damage caused by Ischemia reperfusion (I/R) in skeletal muscles such as bed sores and various spectrums of traumas, surgeries and diseases (Alipour et al., 2011a; Gholami et al., 2015; Ranjbar et al., 2015). It is established that oxidative stress especially generation of reactive oxygen species (ROS) during reperfusion stage is the main reason for the beginning of inflammatory cascade. In fact, oxygen free radicals are important factors that activate nuclear factor kB (NF-kB). $\mathrm{NF}-\mathrm{kB}$ is recognized as a transcription factor that regulates the expression of inflammatory cytokines including tumor

\footnotetext{
${ }^{1}$ Medical Biology Research Center, Kermanshah University of Medical Sciences, Kermanshah, Iran.

${ }^{2}$ Razi Herbal Medicines Research Center, Lorestan University of Medical Sciences, Khorramabad, Iran.

${ }^{3}$ Department of Social Medicine, Lorestan University of Medical Sciences, Khorramabad, Iran.

${ }^{4}$ Student Research Committee, Lorestan University of Medical Sciences, Khorramabad, Iran.

${ }^{5}$ Stem Cells and Tissue Engineering Research Center, Shahroud University of Medical Sciences, Shahroud, Iran.
} 
GHOLAMI, M. R.; ABBASZADEH, A.; ANBARI, K.; KHAKSARIAN, M.; SHABOONI, F.; KHAYAT, Z. K.; KHORRAMABADI, R. M. \& GHARRAVI, A. M. Protective effects of honey, Apis mellifera meda skorikov, on ischemia-reperfusion induced muscle injury. Int. J. Morphol., 38(3):804-810, 2020.

necrosis factor (TNF)-a and interleukin (IL)-6 (Gillani et al.; Sahebkar et al., 2016). These inflammatory proteins specifically TNF- $\alpha$ has a critical role in the development of damage caused by skeletal muscles Ischemia-reperfusion (IR) (Gholami et al., 2015; Zendedel et al., 2017). TNF- $\alpha$ as an inflammatory cytokine in has been distributed different organs. Various biological roles have been defined for it such as proliferation and differentiation of cells, cell apoptosis and playing role in the inflammatory diseases, etc. It has been reported that TNF- $\alpha$ can be implicated in neutrophil migration through the activation of NF-kB. So, use of natural antioxidants to remove oxidative stress particularly ROS could be a good way for preventing lipid peroxidation and inflammatory responses caused by ROS production.

Therapeutic effects of honey have been shown from ancient times until now. It is available in different regions of the world. Honey includes almost 200 different substances. Fructose and glucose with a frequency of 80-85\% are the most abundant components that have been found in honey. Amino acids, enzymes, vitamins and phenolic compounds are the other substances. In addition, honey is a rich source of enzymatic and non-enzymatic antioxidants that are responsible for its antioxidant properties. These antioxidants are ascorbic acid; tocopherols, catalase (CAT), superoxide dismutase (SOD), reduced glutathione (GSH) and flavonoids such as pinocembrin, quercetin, kaempferol and other compounds include phenolic acids. Honey has been used in traditional medicine as a therapeutic agent for treatment of wounds, burns, digestive tracts diseases (diarrhea), respiratory disorders, insomnia, cardiovascular disorders, infectious diseases, anemia, nervous disorders, acute fevers, eye diseases, etc. Today, investigations indicate other properties such as antioxidant, anti-inflammatory, antibacterial, antifungal, antiviral, wound healing, preservative and anti-hyperlipidemic, anti-diabetic, antineoplastic and anti-carcinogenic effects (Eteraf-Oskouei \& Najafi, 2013; Rao et al., 2016; Gholami et al., 2017).

Several investigations have been reported ameliorating effects of honey and its derivative compounds on IRI (Gholami et al., 2018). One study showed that pinocembrin as a main flavonoid compound of honey ameliorates IRI (Saad et al., 2015). Other researchers reported that administration of honey before ischemic phase has protective effects against ischemia-reperfusion injuries of heart (Najafi et al., 2012). Preventive effects of natural honey against gastrointestinal tract ischemia-reperfusion gastric lesions were also examined. (Sasaki \& Joh, 2007).

Therefore, in accordance to the beneficial effects of honey in reducing ischemia-reperfusion injury in various organs, its antioxidant property can be protective against ischemia-reperfusion injury of skeletal muscles. The aim of this study was to evaluate Persian Honey, Apis mellifera meda skorikov, effects on ischemia-reperfusion injury of gastrocnemius muscle.

\section{MATERIAL AND METHOD}

Ethical approval. All of the experimental manuals on animals were conducted with agreement of protocols of the laboratory animal care. These principles were approved by Animal Ethics Committee of Lorestan University of Medical Sciences.

Chemicals. The required following chemicals were obtained: Honey (Garrin Mountain, Khorramabad, Lorestan, Iran), $\mathrm{NaCl}$ (Merck Company), $3 \% \mathrm{H}_{2} \mathrm{O}_{2}$ (Merck Company), h. Tris-Hcl (Merck Company), Formalin, Phosphate buffer, Ketamine, xylazine, Signal Stain ${ }^{\circledR}$ Boost IHC Detection Reagents, Signal Stain ${ }^{\circledR}$ DAB Substrate Kit, Rat anti mouse TNF ALPHA, Rabbit F(ab')2 anti-rat IgG: HRP, HRPStabilizing Diluent and Normal saline.

Honey sampling and preparation: In present study, experiments was conducted by Apis mellifera meda skorikov, a honey obtained from bee keepers in Garrin Mountain, Khorramabad, Lorestan, Iran, prepared by bees feeding on the apple juice in summer (August and September) when sources of nectar and pollen were abundant. The honey was freshly collected from sealed honeycombs, kept in dark glass bottles, and preserved at $10^{\circ} \mathrm{C}$ then diluted with drinking water ( $5 \%$ solution).

Chemical properties of honey: According to previous studies honey contains a number of carbohydrates, proteins and amino acids, vitamins, minerals and antioxidants. Chemical properties of honey was conducted by ASA Laboratory (Tehran, Iran) a partnership of food and drug deputy of health ministry. The carbohydrates present were the monosaccharides fructose $(44.09 \%)$ and glucose $(31.09$ $\%)$ and disaccharides ( 0.99\%) sucrose.

In pilot study we conducted investigation with three dose of $2 \%, 5 \%$ and $10 \%$ honey solution. After several experiments we selected honey in drinking water $(5 \%$ solution).

Animals and study design: Present experimental study was conducted in Razi herbal medicine research center of the Lorestan University of Medical Sciences. Animals were purchased from Razi Herbal Medicine Center of Lorestan University of Medical Sciences. A total of 80 adult male Sprague-Dawley rats at 8 weeks of age (weighing 250-300 
GHOLAMI, M. R.; ABBASZADEH, A.; ANBARI, K.; KHAKSARIAN, M.; SHABOONI, F.; KHAYAT, Z. K.; KHORRAMABADI, R. M. \& GHARRAVI, A. M. Protective effects of honey, Apis mellifera meda skorikov, on ischemia-reperfusion induced muscle injury. Int. J. Morphol., 38(3):804-810, 2020.

g) were housed for 1 week to the situation of the animal laboratory. All animals were maintained with free access to Food standard diet and tap water and with a room temperature of 22 and alternation in light (12-h light: 12-h dark cycle). Then rats were grouped randomly into 10 groups ( 8 per group) as follow:

Group 1: control group (without ischemia-reperfusion), only received water orally by gavage.

Group 2: sham group (without ischemia-reperfusion), received $10 \mathrm{cc}$ honey solution $(5 \%)$ through the oral gavage twice a day.

Group 3: $3 \mathrm{~h}$ of ischemia and 3 days reperfusion with the oral gavage of placebo ( $\mathrm{P}+\mathrm{IR} 3)$.

Group 4: $3 \mathrm{~h}$ of ischemia and 3 days reperfusion together with $10 \mathrm{cc}$ honey solution $(5 \%)$ through the oral gavage twice a day $(\mathrm{H}+\mathrm{IR} 3)$.

Group 5: $3 \mathrm{~h}$ of ischemia and 7 days reperfusion with the oral gavage of placebo (P+IR7).

Group 6: $3 \mathrm{~h}$ of ischemia and 7 days reperfusion together with $10 \mathrm{cc}$ honey solution $(5 \%)$ through the oral gavage twice a day $(\mathrm{H}+\mathrm{IR} 7)$.

Group 7: $3 \mathrm{~h}$ of ischemia and 14 days reperfusion with the oral gavage of placebo (P+IR14).

Group 8: $3 \mathrm{~h}$ of ischemia and 14 days reperfusion together with $10 \mathrm{cc}$ honey solution $(5 \%)$ through the oral gavage twice a day (H+IR14).

Group 9: 3 h of ischemia and 28 days reperfusion with the oral gavage of placebo (P+IR28).

Group 10: $3 \mathrm{~h}$ of ischemia and 28 days reperfusion together with $10 \mathrm{cc}$ honey solution (5\%) through the oral gavage twice a day (H+IR28).

Groups 3, 5, 7, and 9 above were defined as placebo groups and received water instead of honey (Çevik et al., 2013).

Carbohydrate selected as positive control group

Surgical procedure. The procedure of surgery was conducted according to the method of Animal Care and Use Committee. At first, the rats were anesthetized with injection of ketamine $\mathrm{HCl}(50 \mathrm{mg} / \mathrm{kg})$ and xylazine $(5 \mathrm{mg} / \mathrm{kg})$ intraperitoneally (IP). Development of ischemia was done by shaving and disinfecting of the inguinal area. To cause obstruction of femoral artery and vein, an inguinal incision was created and vessels were carefully separated from the nerve, then, artery and vein were knit by using a silk suture 6/ 0 and slipknot technique for $3 \mathrm{~h}$. After time of ischemia, reperfusion was carried out for 3, 7, 14 and 28 days. Honey and water (respectively in experimental and placebo groups), both were given through the oral gavage. The rats were killed after treatment time with a high dose of anesthetic drug and then gastrocnemius muscle removed and fixed in $10 \%$ formalin (Gholami et al., 2008; Alipour et al., 2011b). $10 \%$ of the entire muscle were then sectioned at the mid-belly and embedded in paraffin. Approximately 40 sections were cut at the mid-belly of the muscle. 40 sections were analyzed per muscle.

Histopathologic Studies. For light microscopic studies tissue samples were routinely processed after fixation and then embedding of gastrocnemius muscle in paraffin was started. Sectioning (4-6 $\mu \mathrm{m}$ thick), dehydration and clearing by graded ethanol series and xylene were done, respectively. Then, sections were stained with hematoxylin-eosin staining for edema and fiber degeneration scoring. Mast cells counting and infiltration were conducted by toluidine blue staining. Thirty selected fields of stained tissue sections were randomly evaluated microscopically (magnification of 40). The morphological criteria were considered include disorganization and degeneration of muscle fibers, infiltration of mast cells, and edema of the interstitial fluid on the tissue. Scoring based on these criteria was performed as follow: 0 , normal; 1 , mild; 2, moderate; 3, severe (Jefayri et al., 2000).

Immunohistochemical Studies. TNF-alpha expression was measured Immunohistochemically by using slight adjustments in the protocol of AbD Serotec company (Ostadalova et al., 2007). Tissue samples were deparaffinized in xylene and dehydration of them was done in ethanol. Antigens were recovered in citrate buffer $(\mathrm{pH}=6)$ for $15 \mathrm{~min}$ at $98{ }^{\circ} \mathrm{C}$. Endogenous peroxidase activity as an annoying factor was removed by incubation of specimens with $0.3 \%$ (w/v) $\mathrm{H} 2 \mathrm{O} 2$ in PBS for $15 \mathrm{~min}$. In the next stage, washing was done three times in PBS. After washing, incubation was started with $10 \%$ normal goat serum (Cell signaling, \#5425) for $10 \mathrm{~min}$. Then, tissue sections were incubated overnight with primary antibody (rat anti-mouse TNFalpha, AbD Serotec, \# MCA 1488). Primary antibodies were diluted by adding PBS to them (only negative control samples were diluted) at the ratio of 1:100. After dilution one drop of secondary antibody (Rabbit F ( $\mathrm{ab}^{\prime}$ ) 2 anti-rat IgG: HRP, AbD Serotec, \# STAR21B) was added to samples and they were incubated $30 \mathrm{~min}$. Washing was done. Then, samples were incubated with one drop of diluted Signal Stain ${ }^{\circledR}$ DAB Substrate Kit (Cell signaling, \#8059) with $1 \mathrm{ml} \mathrm{HRP-}$ Stabilizing Diluent (AbD Serotec, \#BUF052C). Samples were washed with PBS; then, they were counterstained with hematoxylin counterstain for $1 \mathrm{~min}$ and immediately washed. Samples were dehydrated and cleared through a graded series of alcohols and xylene, respectively and then mounted.

Statistical Analysis. The statistical analysis of data were done based on Kruskal-Wallis test, Mann-Whitney U test, and Dunn's multiple comparison tests by using SPSS v.22 software. Differences between the groups were analyzed by using Kruskal-Wallis test and the Mann-Whitney U test was utilized for pairwise comparisons. All variables were expressed as the mean \pm SD for each group. 
GHOLAMI, M. R.; ABBASZADEH, A.; ANBARI, K.; KHAKSARIAN, M.; SHABOONI, F.; KHAYAT, Z. K.; KHORRAMABADI, R. M. \& GHARRAVI, A. M. Protective effects of honey, Apis mellifera meda skorikov, on ischemia-reperfusion induced muscle injury. Int. J. Morphol., 38(3):804-810, 2020.

\section{RESULTS}

Histopathologic studies (Mast cell infiltration and Edema). Evaluation of the severity of edema of the interstitial fluid on the tissue suggests a significantly decrease in all of the treated groups $(\mathrm{H}+\mathrm{IR} 3, \mathrm{H}+\mathrm{IR} 7, \mathrm{H}+\mathrm{IR} 14$ and $\mathrm{H}+\mathrm{IR} 28)$ $(\mathrm{p}<0.0001, \mathrm{p}<0.0001, \mathrm{p}=0.01$, and $\mathrm{p}=0.0001$, respectively) as compared with the corresponding placebo group ( $\mathrm{P}+\mathrm{IR} 3$, P+IR7, P+IR14, P+IR28) (Table I, Fig. 1).

The H+IR7 group results display a significant difference compared to the placebo corresponding group ( $\mathrm{p}$ value $=0.028)$. Similarly, the H+IR14 group results showed a significant difference compared to the corresponding untreated group and the sham control group ( $\mathrm{p}$ value $=0.005$ ). But as shown in Table, significant difference was not seen between $\mathrm{H}+\mathrm{IR} 3$ and $\mathrm{H}+\mathrm{IR} 28$ results and their corresponding untreated group (P+IR3, P+IR28) (Table I, Fig. 2).

Immunohistochemistry studies (TNF-alpha expression). Compared to the corresponding untreated, the amount of TNF-alpha expression significantly decreased in the H+IR7, $\mathrm{H}+\mathrm{IR} 14$ and H+IR28 groups $(\mathrm{p}<0.0001, \mathrm{p}<0.0001$, $\mathrm{p}<0.0001$, respectively). However, decreased amount was not significant in H+IR3 (Table I, Fig. 3).

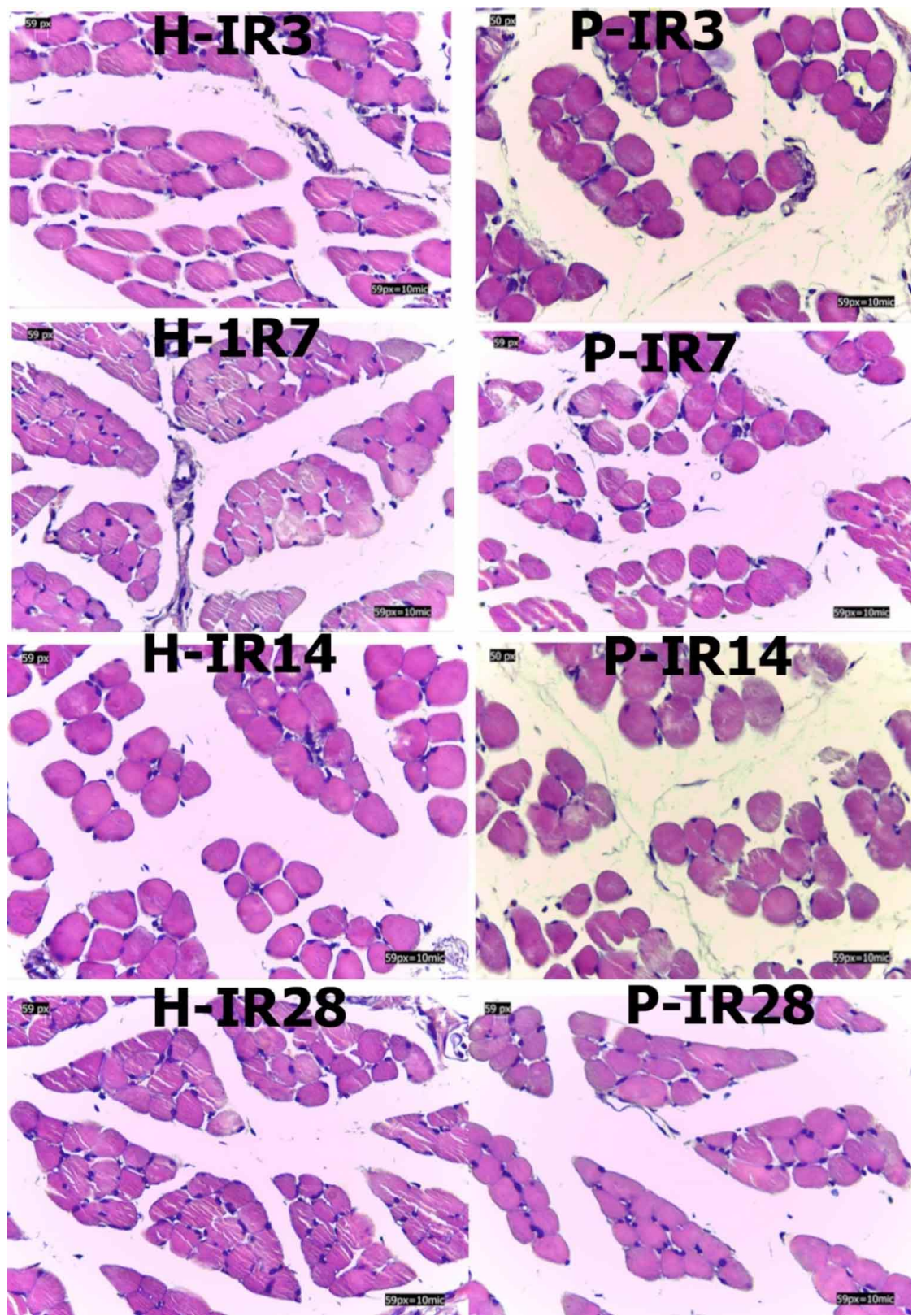

Fig. 1. Severity of edema is shown in different groups by using H\&E staining.

\section{DISCUSSION}

Skeletal muscle injury caused by ischemia-reperfusion develops severe complications. Post ischemic reperfusion and subsequently generation of ROS is a serious factor for development of damage to cells (Wang et al., 2016). So, we decided to evaluate ameliorative effect of honey on ischemia-reperfusion injury.

Our results demonstrated that the IR injury caused by gastrocnemius muscle is defined by mast cell infiltration, tissue edema and expression of inflammatory cytokines. Moreover, our study showed that honey can significantly ameliorate IR-induced skeletal muscle injury.

The present study showed a significantly decrease in mast cells infiltration in the gastrocnemius muscle tissue of treated groups with honey. Mast cells lived in the different tissue for a long time. They produce various biological mediators such as histamine, inflammatory cytokines including tumor necrosis factor (TNF) and involved in immune responses. They also seen in other conditions include ischemia-reperfusion condition in tissues like skeletal muscles, heart muscles, lung, and small intestine. Therefore, mast cells 


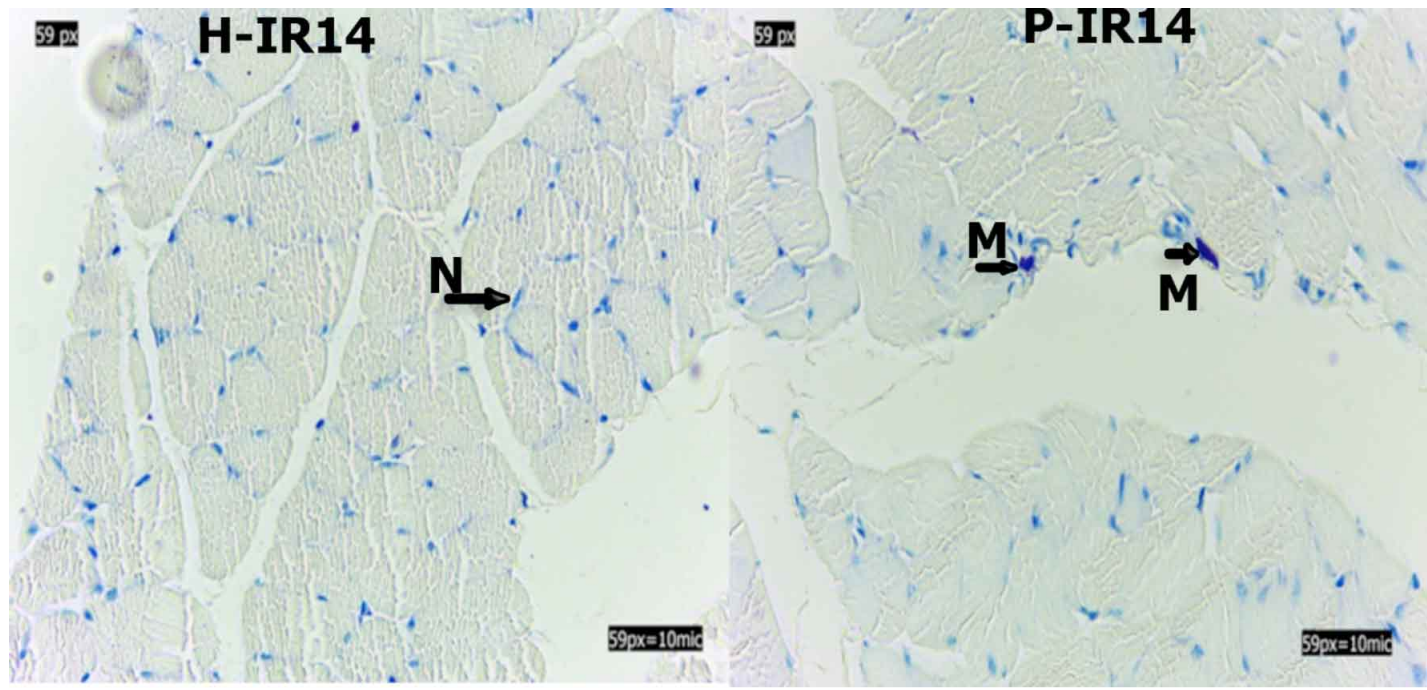

Fig. 2. Infiltration of mast cells is shown in muscular tissue by using toluidine blue staining. The purple spots are mast cells. N; nucleous, M; mast cells.

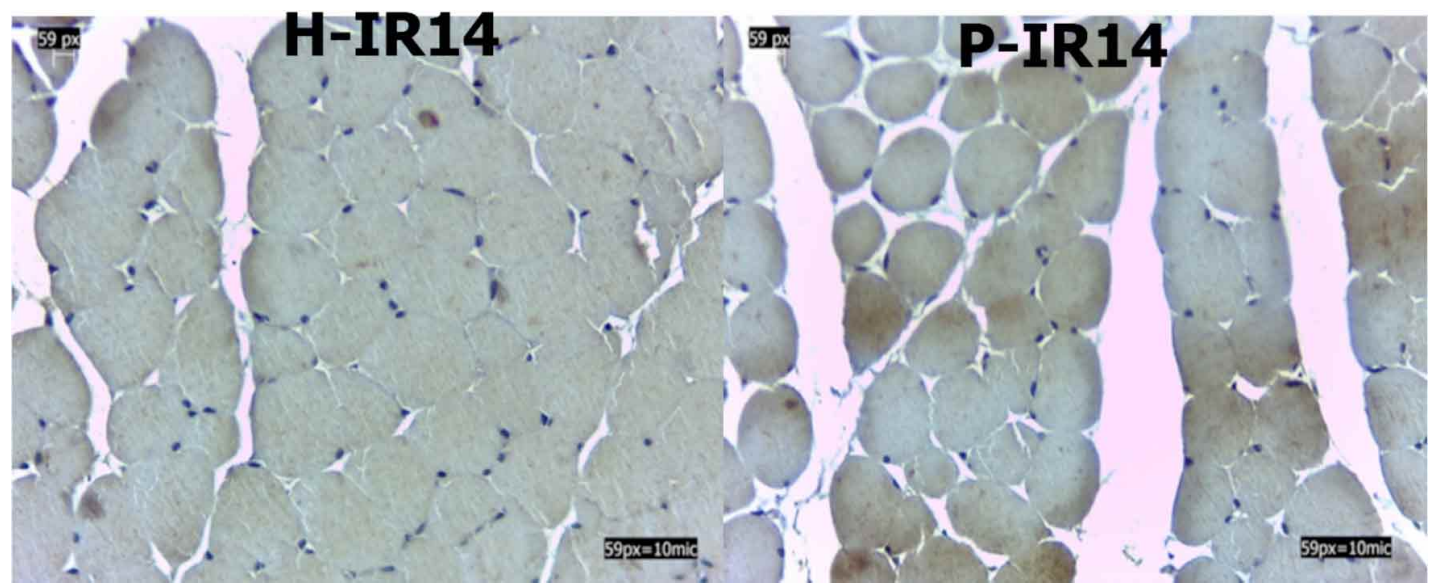

Fig. 3. TNF-alpha expression, brown spots, is detected in 14 day by using immunohistochemistry method.

Table I. Comparison of mast cell infiltration, edema and TNF-alpha expression in different days of reperfusion between different groups is shown.

\begin{tabular}{|c|c|c|c|c|c|c|c|c|c|}
\hline \multirow[t]{2}{*}{ Group } & \multicolumn{3}{|c|}{ Mast cell infiltration (cells $/ \mathrm{mm}^{2}$ ) } & \multicolumn{3}{|c|}{ Edema $(\%)$} & \multicolumn{3}{|c|}{ TNF-alpha expression (pg/ml) } \\
\hline & Mean \pm SD & Average & P value & Mean \pm SD & Average & $\mathrm{P}$ value & Mean \pm SD & Average & P value \\
\hline \multirow[t]{2}{*}{$\mathrm{H}+\mathrm{IR} 3$} & $1.87 \pm 1.24$ & 8.13 & 0.798 & $0.62 \pm 0.51$ & 4.5 & 0.0001 & $9.12 \pm 3.75$ & 7.38 & 0.382 \\
\hline & & & & & & & $10.62 \pm 3.58$ & 9.63 & \\
\hline $\mathrm{P}+\mathbb{R} 3$ & $2 \pm 1.69$ & 8.88 & & $3.25 \pm 0.46$ & 12.5 & & & & \\
\hline \multirow[t]{2}{*}{$\mathrm{H}+\mathrm{IR} 7$} & $1.75 \pm 1.03$ & 5.88 & 0.028 & $1.62 \pm 0.51$ & 4.5 & 0.0001 & $1.62 \pm 0.74$ & 4.5 & 0.0001 \\
\hline & & & & & & & $10.12 \pm 2.16$ & 12.5 & \\
\hline $\mathrm{P}+\mathbb{R} 7$ & $3.87 \pm 2.35$ & 11.13 & & $3.62 \pm 0.51$ & 12.5 & & & & \\
\hline $\mathrm{H}+\mathrm{IR} 14$ & $3.25 \pm 1.66$ & 5.31 & 0.005 & $1.87 \pm 0.83$ & 5.5 & 0.01 & $2.25 \pm 2.18$ & 4.5 & 0.0001 \\
\hline $\mathrm{P}+\mathbb{R} 14$ & $6 \pm 2.26$ & 11.69 & & $3.37 \pm 0.91$ & 11.5 & & $10.5 \pm 2.72$ & 12.5 & \\
\hline $\mathrm{H}+\mathrm{IR} 28$ & $2.25 \pm 1.16$ & 6.56 & 0.105 & $1.75 \pm 0.7$ & 4.56 & 0.0001 & 0 & 4.5 & 0.0001 \\
\hline $\mathrm{P}+\mathrm{IR} 28$ & $4.12 \pm 2.74$ & 10.44 & & $4 \pm 0.53$ & 12.44 & & $6.62 \pm 2.32$ & 12.5 & \\
\hline
\end{tabular}

Data are expressed as the mean \pm SD. Statistical analysis was done using the Mann-Whitney U test.

play critical role in the ischemia-reperfusion process (De Filippo et al., 2013; Gholami et al., 2015). Other studies showed that different array of antioxidants such as caffeic acid phenethyl ester (CAPE) as an active substance of honey can reduce ischemia-reperfusion injury in the gastrocnemius muscle by reduction in amount of mast cells and neutrophils 
(Andrade-Silva et al., 2009). Gholami et al. (2015) indicated that reduction in the number of mast cells play a central role in amelioration of ischemia-reperfusion injury of gastrocnemius muscle. In addition, other related studies have been suggested that ischemia-reperfusion injury can reduce by using various antioxidants (Gholami et al., 2007, 2008). Furthermore, honey showed that can prevents damage caused by ischemia-reperfusion via decreased ede$\mathrm{ma}$, tissue structure disorganization, and degeneration.

There are many reasons such as different variety of diseases for development of muscle edema. Edema is characterized by increase in volume of muscle as a result of accumulation of fluid content (Cho \& Atwood, 2002; McMahon et al., 2010).

A related study showed that selenium as an antioxidant can reduce edema caused by gastrocnemius muscle ischemia-reperfusion injury (Gholami et al., 2015). One study demonstrated that Pinocembrin as one of the most important flavonoid of honey has decreasing effect on brain edema (Saad et al.). Wang et al. approved that Colchicine has a protective effect against gastrocnemius muscle damage caused by ischemia/reperfusion through reduce in edema. Other antioxidants such as simvastatin, aminoguanidine and quercetin can also attenuate edema and ischemic fiber degeneration in the models of peripheral nerve damage caused by ischemia-reperfusion (Gholami et al., 2008).

In addition to the mast cell infiltration and muscle edema, honey can decrease expression of TNF- $\alpha$. TNF- $\alpha$ is a pro-inflammatory cytokine that acts as an endogenous pyrogenic factor. It involves in inflammation (release of IL-6, IL-8 and IL-1b), apoptosis and activation and infiltration of polymorphonuclear neutrophils, etc. Atherosclerosis, cancer, and inflammatory bowel disease are some of diseases that are created caused by increase in TNF- $\alpha$ amount (Ma et al., 2016). Many inflammatory cells can produce TNF- $\alpha$ like activated macrophages, CD4+ lymphocytes, NK cells, neutrophils, mast cells, eosinophil, and nerve cells. Another biological function of TNF- $\alpha$ is activation of NF-kB. NF-kB is recognized as a transcription protein that play role in diagnosis of apoptosis. It is demonstrated that this nuclear factor is the beginner of inflammatory and anti-apoptotic genes transcription. Therefore, inactivation of NF-kB pathway by using decrease in TNF- $\alpha$ expression can ameliorate ischemiareperfusion injury. Gholami et al. (2015) demonstrated that Selenium play ameliorative role in ischemia/reperfusion of gastrocnemius muscle. They observed that this antioxidant can reduce the expression of TNF- $\alpha$. Other studies showed that Colchicine has a protective effect against gastrocnemius muscle damage caused by ischemia/ reperfusion injury via decreased amounts of TNF-a expression (Wang et al.). Therefore, decrease in expression of TNF- $\alpha$ as an inflammatory marker, amount of edema and mast cells infiltration regarded to our results has a significant correlation with honey long-term IR treatment.

\section{CONCLUSION}

In conclusion, our results showed that pre-ischemia honey treatment attenuates gastrocnemius muscle IR injury via reduction in the inflammatory events. Therefore, honey treatment approves the antioxidant therapy hypothesis for overcome against skeletal muscle injury induced by IR and may be effective as a therapeutic strategy. So, more studies in this field are required.

GHOLAMI, M. R.; ABBASZADEH, A.; ANBARI, K.; KHAKSARIAN, M.; SHABOONI, F.; KHAYAT, Z. K.; KHORRAMABADI, R. M. \& GHARRAVI, A. M. Efectos protectores de la miel, Apis mellifera meda skorikov, sobre la lesión muscular inducida por isquemia-reperfusión. Int. J. Morphol., 38 (3):804-810, 2020.

RESUMEN: La miel es un antioxidante natural; sus efectos protectores han sido probados contra la lesión por isquemiareperfusión (IR). El objetivo de este estudio fue evaluar el efecto de mejora de la miel persa Apis mellifera meda skorikov, en la lesión por IR del músculo gastrocnemio. Se utilizaron 80 ratas Sprague-Dawley macho adultas con un peso entre 250 y $300 \mathrm{~g}$ divididas en diez grupos ( $\mathrm{N}=8$ por grupo). La isquemia se realizó con una sutura de seda 6-0 utilizando la técnica slipknot permaneciendo isquémicos durante $3 \mathrm{~h}$. La reperfusión se realizó durante varios tiempos de 3 días, 7 días (reperfusión de 7 días), 14 días (reperfusión de 14 días) y 28 días (28 días reperfusión). La mitad de los grupos recibió tratamiento experimental con miel (5\%) inmediatamente después de la isquemia. Después de la reperfusión, las ratas, fueron sacrificadas con altas dosis de anestésico, y los músculos gastrocnemios fueron removidos y fijados. Después de procesar el tejido, se realizó la evaluación del edema y la infiltración de mastocitos se realizó con tinción de hematoxilina-eosina y azul de toluidina, respectivamente. TNF- $\alpha$ se detectó con el método de inmunohistoquímica. La cantidad de TNF- $\alpha$ como índice de inflamación inflamatoria aguda, excepto en el tercer día, disminuyó significativamente al día siguiente de la reperfusión (7, 14 y 28 días). La infiltración de mastocitos disminuyó significativamente a los 7 y 14 días. El edema tisular disminuyó significativamente en el grupo administrado con miel en comparación con los grupos placebo. El tratamiento con miel puede reducir el daño causado por la isquemia-reperfusión en el músculo gastrocnemio de la rata.

PALABRAS CLAVE: Miel; Lesión por isquemiareperfusión; Músculo gastrocnemio; Rata. 


\section{REFERENCES}

Aksu, V.; Yüksel, V.; Chousein, S.; Tastekin, E.; Iscan, S.; Sagiroglu, G.; Canbaz, S. \& Sunar, H. The effects of sildenafil and n-acetylcysteine on ischemia and reperfusion injury in gastrocnemius muscle and femoral artery endothelium. Vascular, 23(1):21-30, 2015.

Alipour, M.; Gholami, M. R.; Jafari Anarkooli, I.; Sohrabi, D.; Tajki, J. \& Pourheidar, M. Intraperitoneal aminoguanidine improves sciatic nerve ischemia-reperfusion injury in male sprague-dawley rats. Cell. Mol. Neurobiol., 31(5):765-73, 2011a.

Alipour, M.; Sohrabi, D.; Gholami, M. \& Jafari Anarkooli, I. The role of aminoguanidine on functional recovery of rat reperfused sciatic nerve. J. Adv. Med. Biomed. Res., 19(77):9-21, 2011b.

Andrade-Silva, A. R.; Ramalho, F. S.; Ramalho, L. N.; Saavedra-Lopes, M.; Jordão, A. A. Jr.; Vanucchi, H.; Piccinato, C. E. \& Zucoloto, S. Effect of NFkappaB inhibition by CAPE on skeletal muscle ischemiareperfusion injury. J. Surg. Res., 153(2):254-62, 2009.

Çevik, Ö.; Çadırcı, S.; Sener, T.; Tinay, I.; Akbal, C.; Tavukçu, H. H.; Çetinel, S.; Kıran, D. \& Sener, G. Quercetin treatment against ischemia/ reperfusion injury in rat corpus cavernosum tissue: a role on apoptosis and oxidative stress. Free Radic. Res., 47(9):683-91, 2013.

Cho, S. \& Atwood, J. E. Peripheral edema. Am. J. Med., 113(7):580-6, 2002.

De Filippo, K.; Dudeck, A.; Hasenberg, M.; Nye, E.; van Rooijen, N.; Hartmann, K.; Gunzer, M.; Roers, A. \& Hogg, N. Mast cell and macrophage chemokines CXCL1/CXCL2 control the early stage of neutrophil recruitment during tissue inflammation. Blood, 121(24):4930-7, 2013.

Dong, X.; Xing, Q.; Li, Y.; Han, X. \& Sun, L. Dexmedetomidine protects against ischemia-reperfusion injury in rat skeletal muscle. J. Surg. Res., 186(1):240-5, 2014

Eteraf-Oskouei, T. \& Najafi, M. Traditional and modern uses of natural honey in human diseases: a review. Iran. J. Basic Med. Sci., 16(6):73142, 2013.

Gharravi, A. M.; Orazizadeh, M. \& Hashemitabar, M. Fluid-induced low shear stress improves cartilage like tissue fabrication by encapsulating chondrocytes. Cell Tissue Bank., 17(1):117-22, 2016.

Gholami, M. R.; Abolhassani, F.; Pasbakhsh, P.; Akbari, M.; Sobhani, A.; Eshraghian, M. R.; Kamalian, N.; Amoli, F. A.; Dehpour, A. R. \& Sohrabi, D. The effects of simvastatin on ischemia-reperfusion injury of sciatic nerve in adult rats. Eur. J. Pharmacol., 590(1-3):111-4, 2008.

Gholami, M. R.; Abolhassani, F.; Pasbakhsh, P.; Akbari, M.; Sobhani, A.; Sohrabi, D. \& Mehrania, K. The effects of simvastatin on functional recovery of rat reperfused sciatic nerve. Pak. J. Biol. Sci., 10(23):425660, 2007.

Gholami, M.; Abbaszadeh, A.; Khanipour Khayat, Z.; Anbari, K.; Baharvand, P. \& Gharravi, A. M. Honey improves spermatogenesis and hormone secretion in testicular ischaemia-reperfusion-induced injury in rats. Andrologia, 50(1), 2018. doi: 10.1111/and.12804

Gholami, M.; Khayat, Z. K.; Anbari, K.; Obidavi, Z.; Varzi, A.; Boroujeni, M. B.; Alipour, M.; Niapoor, A. \& Gharravi, A. M. Quercetin ameliorates peripheral nerve ischemia-reperfusion injury through the NF-kappa B pathway. Anat. Sci. Int., 92(3):330-7, 2017.

Gholami, M.; Zendedel, A.; Khanipour khayat, Z.; Ghanad, K.; Nazari, A. $\&$ Pirhadi, A. Selenium effect on ischemia-reperfusion injury of gastrocnemius muscle in adult rats. Biol. Trace Elem. Res., 164(2):205$11,2015$.

Gillani, S.; Cao, J.; Suzuki, T. \& Hak, D. J. The effect of ischemia reperfusion injury on skeletal muscle. Injury, 43(6):670-5, 2012.

Jalili, C.; Tabatabaei, H.; Kakaberiei, S.; Roshankhah, S. \& Salahshoor, M. R. Protective role of crocin against nicotine-induced damages on male mice liver. Int. J. Prev. Med., 6:92, 2015.

Jefayri, M. K.; Grace, P. A. \& Mathie, R. T. Attenuation of reperfusion injury by renal ischaemic preconditioning: the role of nitric oxide. $B J U$ Int., 85(9):1007-13, 2000.
Joshi, S. K.; Lee, L.; Lovett, D. H.; Kang, H.; Kim, H. T.; Delgado, C. \& Liu, X. Novel intracellular N-terminal truncated matrix metalloproteinase-2 isoform in skeletal muscle ischemia-reperfusion injury. J. Orthop. Res., 34(3):502-9, 2016.

Ma, K.; Zhang, H. \& Baloch, Z. Pathogenetic and therapeutic applications of Tumor Necrosis Factor-a (TNF-a) in major depressive disorder: a systematic review. Int. J. Mol. Sci., 17(5):E733, 2016.

McMahon, C. J.; Wu, J. S. \& Eisenberg, R. L. Muscle edema. AJR Am. J. Roentgenol., 194(4):W284-92, 2010.

Najafi, M.; Zahednezhad, F.; Samadzadeh, M. \& Vaez, H. Zero flow global ischemia-induced injuries in rat heart are attenuated by natural honey. Adv. Pharm. Bull., 2(2):165-71, 2012.

Ostadalova, I.; Vobecky, M.; Chvojkova, Z.; Mikova, D.; Hampl, V.; Wilhelm, J. \& Ostadal, B. Selenium protects the immature rat heart against ischemia/reperfusion injury. Mol. Cell. Biochem., 300(1-2):25967, 2007.

Ranjbar, K.; Nazem, F.; Nazari, A.; Gholami, M.; Nezami, A. R.; Ardakanizade, M.; Sohrabi, M.; Ahmadvand, H.; Mottaghi, M. \& Azizi, Y. Synergistic effects of nitric oxide and exercise on revascularisation in the infarcted ventricle in a murine model of myocardial infarction. EXCLI J., 14:1104-15, 2015.

Rao, P. V.; Krishnan, K. T.; Salleh, N. \& Gan, S. H. Biological and therapeutic effects of honey produced by honey bees and stingless bees: a comparative review. Rev. Bras. Farmacogn., 26(5):657-64, 2016.

Saad, M. A.; Abdel Salam, R. M.; Kenawy, S. A. \& Attia, A. S. Pinocembrin attenuates hippocampal inflammation, oxidative perturbations and apoptosis in a rat model of global cerebral ischemia reperfusion. Pharmacol. Rep., 67(1):115-22, 2015.

Sahebkar, A.; Cicero, A. F. G.; Simental-Mendía, L. E.; Aggarwal, B. B. \& Gupta, S. C. Curcumin downregulates human tumor necrosis factor-a levels: A systematic review and meta-analysis ofrandomized controlled trials. Pharmacol. Res., 107:234-42, 2016.

Salahshoor, M. R.; Khashiadeh, M.; Roshankhah, S.; Kakabaraei, S. \& Jalili, C. Protective effect of crocin on liver toxicity induced by morphine. Res. Pharm. Sci., 11(2):120-9, 2016. (2016b)

Salahshoor, M.; Mohamadian, S.; Kakabaraei, S.; Roshankhah, S. \& Jalili, C. Curcumin improves liver damage in male mice exposed to nicotine. J. Tradit. Complement. Med., 6(2):176-83, 2015. (2016a)

Sasaki, M. \& Joh, T. Oxidative stress and ischemia-reperfusion injury in gastrointestinal tract and antioxidant, protective agents. J. Clin. Biochem. Nutr., 40(1):1-12, 2007.

Wang, L.; Shan, Y.; Chen, L.; Lin, B.; Xiong, X.; Lin, L. \& Jin, L. Colchicine protects rat skeletal muscle from ischemia/reperfusion injury by suppressing oxidative stress and inflammation. Iran. J. Basic Med. Sci., 19(6):670-5, 2016.

Zendedel, A.; Gharibi, Z.; Anbari, K.; Abbaszadeh, A.; Khayat, Z. K.; Khorramabadi, R. M.; Soleymaninejad, M. \& Gholami, M. Selenium ameliorate peripheral nerve ischemic-reperfusion injury via decreased TNF-a. Biol. Trace Elem. Res., 176(2):328-37, 2017.

\section{Corresponding author:}

Dr. Anneh Mohammad Gharravi

Stem Cells and Tissue Engineering Research Center

Shahroud University of Medical Sciences

Shahroud

Post Code: 3614773955

IRAN

\section{Email: annehgh@yahoo.com gharravi@shmu.ac.ir}

Received: 06-12-2019

Accepted:04-03-2020 